Kirja-arvio

\title{
Harkitusti perinnearkistoista
}

\author{
Harvilahti, Lauri, Audun Kjus, Clíona O'Carroll, Susanne Österlund-Pötzsch, \\ Fredrik Skott ja Rita Treija (toim.). 2018. Visions and Traditions: Knowledge \\ Production and Tradition Archives. FF Communications 315. Helsinki: \\ Suomalainen tiedeakatemia. 384 sivua.
}

\section{Karina Lukin}

$\mathrm{V}$ isions and traditions on tärkeä kirja. Artikkelikokoelman taustalla on perinnearkistoissa tai arkistoaineistojen kanssa tällä hetkellä työskentelevien aktiivisten tutkijoiden joukko, joka ei pelkää kääntää kiviä ja joka on kyllin rohkea sanomaan: "Tämä vuori siirretään, mutta se siirretään hitaasti ja taiten." Kokonaisuutena luettuna kirjan tarjoama näkymä on laaja ja syvä ja sellaisena hengästyttävän ihailtava, mutta artikkeleita voi lukea myös yksitellen, ja sellaisina ne toiminevat esimerkiksi opetusmateriaaleina.

Koko kokoelman läpi kulkee ajatus perinnearkistojen materiaalien monimuotoisuudesta ja -äänisyydestä, vuorovaikutuksellisuudesta ja intiimiydestä. Nämä tekevät aineistoista, niiden parissa työskentelystä, arkistoinnista, tutkimuksesta ja mahdollisesta julkaisemisesta erityistä.

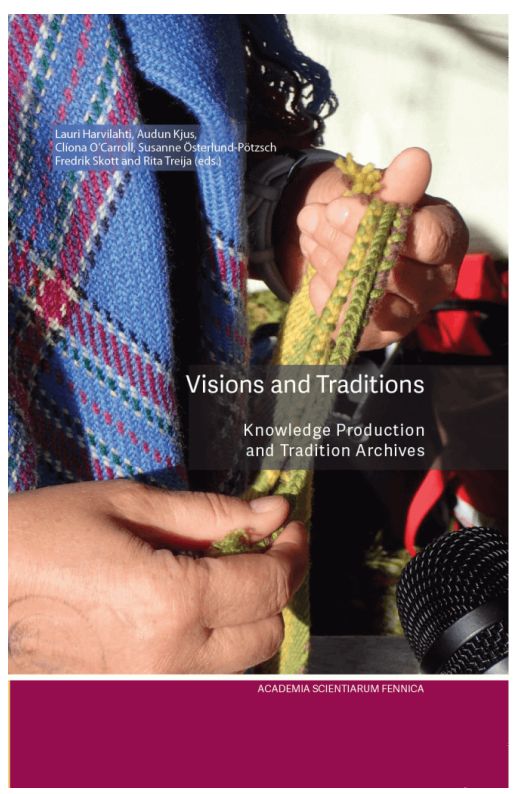
Esimerkiksi Clíona O'Carroll luonnehtii keräämiään muistitietoaineistoja nykyisyyteen ja menneisyyteen, arkiseen ja yliluonnolliseen kuuluviksi runsaiksi ja rosoisiksi kertomuksiksi, joissa tulee ilmi muistin ja muistelun välittömyys ja henkilökohtaisuus. Toisaalla lainataan Timothy Tangherlinia, jonka mainiossa luonnehdinnassa perinnearkistojen aineistoja kuvaillaan meluisiksi (noisy) ja juuri siksi kiinnostaviksi huolimatta epätasaisuuksista, painotuksista ja aukkoisuudesta.

\section{Kiistanalainen perinnearkisto}

Kokoelmassa avataan aineistoja sekä menneisyyden keruukäytänteiden ja niiden taustojen että nykyisten ja tulevaisuuden haasteiden kautta. Teksteissä palataan kuitenkin tuon tuosta pohtimaan, mikä tekee tai on tehnyt perinnearkistoista erityisen. Ilahduttavaa on, 
että pohdinnoissa ei juurikaan eksytä kehumaan omaa alaa sen oikeuttamisen vuoksi, vaan keskustelu on kriittistä ja avartavaa.

Maryna Chernyavskan artikkeli, joka avaa kokoelman johdantoartikkelin jälkeen, on vakuuttava ja uusia näkökulmia avaava teksti siitä, miksi perinnearkistot ovat arkistojen yleisemmällä kentällä tai arkistotutkimuksen määritelmien näkökulmasta erilaisia ja siksi kiistanalaisia tai ongelmallisia. Chernyavska listaa kuusi syytä, joista aineistojen (1) arkipäiväisyys, niiden (2) elävyys tai dialogisuus, ilmiöitä eri näkökulmista avaava (3) monimuotoisuus ja (4) luonne kulttuurisena tietona tuovat esiin edellä mainittua meluisuutta. Kun perinneaineistoja verrataan esimerkiksi kuvitellun keskimääräisen historiallisen arkiston aineistoihin, paljastuu, että aineistot eivät ole virallisia, lopullisina pidettyjä tietoja, joita ovat tuottaneet tietyissä asemissa olevat henkilöt joidenkin instituutioiden käytänteiden vuoksi, jotta yhteiskunnalla olisi itsestään ja sen yksilöistä tarvittavaa tietoa.

Näihin neljään seikkaan kiinnittyvät ne kaksi tekijää, jotka tekevät perinnearkistoista kiistanalaisen: (5) arkistot käyttävät usein aineiston järjestämisessä ja kuvailussa paikallistason sanastoa, ja (6) ne toimivat yhtäaikaisesti kokoelmien luojina tai kerääjinä sekä niiden ylläpitäjinä. Toisin sanottuna perinnearkistot eivät käytä kansainvälisiä standardeja, eivätkä ne ylläpidä selkeitä kokoelmien ja asiakirjojen välisiä hierarkkisia eroja. Ongelma näyttää ensin hiusten halkomiselta, mutta kun tiedon tai totuuden positivististen määritelmien rinnalle on noussut subjektiivisen merkitystä korostavia ääniä, alkavat perinnearkistojen käytännöt näyttäytyä merkittäviltä myös muiden arkistojen näkökulmasta. Kiistanalainen moniäänisyys ja vuorovaikutuksellisuus ovatkin merkityksellisiä ohjenuoria.

Chernyavskan lisäksi vastaavia kysymyksiä nousee esiin myös Lauri Harvilahden ja Alf Arvidssonin artikkeleissa, jotka molemmat tuovat esiin arkistojen syntymisen, luomisen ja organisoinnin teemoja sekä arkiston ja kentän välistä vuorovaikutusta. Arvidssonin esimerkki käsittelee jazz-musiikin tekemiseen ja esittämiseen liittyvän tiedon arkistointia, ja se tuo Harvilahden tekstin ohella erinomaisesti esiin, miten arkiston luomiseen liittyvä työ on jalkaantumista ja dialogia ihmisten parissa ja miten merkityksettömältä tällainen työ saattaa vaikuttaa jopa itse tutkittavien näkökulmasta. Merkittävyys nousee esille kenties myöhemmin, kun jokapäiväisen arvottomalta tuntuneet yksityiskohdat ja keskustelut ovat karanneet muistoista, ja arkisto kykenee tarjoamaan aineistojensa avulla välineitä - ei vain muisteluun ja muistamiseen vaan myös monitasoiseen reflektioon.

\section{Paradigmoja ja partnereita}

Kokoelman toisen ja kolmannen osan artikkelit luovat hengästyttävän katsauksen perinnearkistojen historiaan. Tämänkaltaiset artikkelit ovat äärimmäisen tärkeitä kunkin tutkimusalan ja arkistotyön omakuvan luomisen kannalta mutta niin ikään alojen kehittämisen ja kehittymisenkin vuoksi. Yksittäiset artikkelit tyytyvät ymmärrettävästi katsastamaan menneisyyksiä kansallisella tasolla, mutta yhdessä ne tuottavat kuvan yhtenäisistä eurooppalaisista tai ainakin pohjoiseurooppalaisista linjoista.

Artikkelien perusteella voi todeta, että meluisten aineistojen rinnalla kulkee ihan yhtä meluisia paradigmoja, jotka ovat vaikuttaneet aineistojen kerääntymiseen. Mutta näiden tieteellisten paradigmojen ja niihin liittyvien käytäntöjen lisäksi arkistoon päätyviin aineistoihin vaikuttavat luonnollisesti myös yhteiskunnan ideologiat, kerääjien ja informanttien välinen 
vuorovaikutus, henkilökohtaiset suhteet ja yksilöiden omat mieltymykset sekä kenttätyötä avittavat tai vaikeuttavat käytännön olosuhteet.

Perinteen tai folkloren keräämiseen vaikuttaneista paradigmoista merkittävimpänä voi näidenkin artikkelien perusteella pitää 1800- ja 1900-luvun vaihteen linjoja, jotka pyrkivät kartoittamaan perinnettä historiallisesti ja paikallisesti säännönmukaisesti varioivina yksikköinä. Näihin paradigmoihin kuuluvat yhtä hyvin maantieteellis-historiallinen metodi kuin Wörter und Sachen -menetelmäkin. Molemmat ylläpitivät laajoja, systemaattisia keruuohjelmia. Kirjaa lukiessa toistuvatkin keltaisten motiivi-indeksien nimet ja tiedot teksteistä, joissa kuvataan yksityiskohtaisesti paikallisperinteiden muotoja ja sisältöjä. Nämä ovat kenties puuduttavaa luettavaa, mutta niiden hyödyllisyyttä tai merkitystä tai niihin uhrattujen työtuntien määrää ei käy kiistäminen. Artikkelien perusteella syntyy hienosti kuva, josta voi tarkastella, miten yksityiskohtienkin väliltä tai taustalta jäi puuttumaan sittenkin jotain vastaajista ja ihmisistä, perinteen yhteisöllisistä ja yksilöllisistä merkityksistä. Puute tai sen havaitseminen johti lopulta paradigman muutokseen.

Samaan aikaan historialliset artikkelit tuovat esiin, miten hidas prosessi paradigman muutos on käytännössä. Yksilöä, yhteisöä ja esittämisen tilanteiden merkityksiä korostava tutkimusote alkoi nousta esiin jo 1960-luvun keskusteluissa, mutta aineiston keruussa ja arkistoinnissa vanhemmat näkemykset vaikuttivat vielä pidempään. Selitys on inhimillinen: muutos kiinnittyy aina yksittäisiin henkilöihin ja erilaisiin institutionaalisiin tapoihin toimia, mutta se liittyy myös tutkimuksen yhteiskunnalliseen oikeuttamiseen. Luulisin, että viimeisellä on ollut merkitystä siinä, että viimeisten runolaulajien, taitajien, tietäjien ja tiedonmurusten retoriikka pitää edelleen pintansa.

Arkistojen historiasta kertovat luvut kuvailevat kauniisti kerääjien, informanttien ja keruuverkostojen vuorovaikutusta, yksittäisiä suhteita ja vastaajien motivaatioita. Vaikka menneisyyttä on ollut tapana tarkastella positivismin arvottavan prisman läpi, tarkemmin katsottuna esimerkiksi keruuverkostojen työstä nousee esille omistautumista, dialogisuutta ja perehtyneisyyttä, joiden perusteella vastaajia tarkastellaan ennemminkin yhteistyökumppaneina ja aktiivisina toimijoina. Aivan ihastuttavalla tavalla tällaista vuorovaikutusta kuvailee Susanne Nylund Skog artikkelissaan, joka käsittelee professori Karl Gösta Gilstringin ja kotirouva Elsa Pihlin kirjeenvaihtoa. 17 vuotta kestäneen yhteydenpidon aikana Pihl kirjoitti yli 230 perinnetietoa sisältävää kirjettä tai postikorttia Gilstringille. Myös muissa artikkeleissa tulee esiin vastaajaverkoston ja informanttien vuorovaikutuksen perusteella rakentuva ymmärrys arkiston haluaman materiaalin luonteesta, mutta niin ikään vastaajien lukuisat niin kansallisuusaatteeseen kuin henkilökohtaisiin vaikuttimiinkin liittyvä into.

\section{Tietokone ja verkot}

Visions and traditions -kokoelman parhainta antia - tai ainakin ajankohtaisinta - tarjoavat kirjan neljännen osan artikkelit, joissa pohditaan tämän hetken ja tulevaisuuden haasteita. Suurin osa artikkeleista kiinnittyy tavalla tai toisella digitalisaatioon, digitoimiseen ja avoimeen tietoon. Näistä on jo pitkään keskusteltu perinnearkistojenkin yhteydessä, ja valitettavan usein vaativaa ja hidasta työtä edellyttäviä digihankkeita reunustaa helppoutta ja kaikkiin ongelmiin ratkaisun tuovaa autuutta korostava hype sekä tekninen munkkilatina. Tässä artikkelikokoelmassa on toisin, mikä on riemastuttavaa. Esimerkiksi Eldar Heide varoittaa sudenkuopista, jotka liittyvät naiiviin presentismiin ja digitoimiseen digitoimisen ilosta. 
Sanita Reinsonen artikkeli toimii melkein vastauksena Heidelle: Reinsone tuo perustellusti esiin, miten perinnearkistoissa on harjoitettu tänä päivänä muodikasta joukkoistamista, eli suuren yleisön osallistamista aineiston keruuseen ja käsittelyyn, jo vuosisatojen ajan. Reinsone jatkaa osoittamalla, miten sähköisten apuvälineiden avulla joukkoistamista voidaan jatkaa niin, että aineistot rikastuvat ja elävöittyvät ja arkiston ja yhteiskunnan välinen vuorovaikutus säilyy.

Kokoelman päättävät Fredrik Skottin, Clíona O'Carrollin ja Audun Kjusin artikkelit käyvät kaikki upealla tavalla läpi digitointiin liittyviä kysymyksiä. Kukaan ei ole tarjoamassa helppoja ratkaisuja, vaan kaikilla kirjoittajilla on kriittisesti, avoimesti ja rehellisesti pohdiskeleva eetos, jonka mukana lukija voi oppia vaikeistakin asioista uutta ja yhtyä keskusteluun. Perusoivallus on, että digitalisaation edessäkin perinnearkistojen meluisat ja kulttuurisesti tiheät aineistot ovat sillä tavoin intiimejä ja henkilökohtaisia, että niitä tulee käsitellä hitaasti, kuten O'Carroll toteaa. Digitalisaatio ei sinänsä tuo aineiston laatuun mitään uutta, mutta perinnearkistojen pitkän linjan ymmärrys aineistoista auttaa ratkomaan monia avoimuuteen liittyviä ongelmia ja perustelemaan ratkaisuja.

Ongelmat, haasteet ja niiden ratkaisut palaavat toistuvasti yhteiskunnallisiin hierarkioihin. Artikkelit pohtivatkin lukuisissa kohdissa ihmisten arkiseen elämään ja siihen liittyvän puheen ja esineistön tallettamiseen ja arvottamiseen liittyviä käytänteitä ja valtaa. Jos kokoelman loppupuolen artikkelit ovat tässä suhteessa erityisen arvokkaita, ajankohtaisia ja helppoja ratkaisuja vältteleviä, historiallisissa teksteissä esiintyy tuon tuostakin taitava arkistotutkija, joka pystyi erehtymättä erottamaan aidon ja epäaidon - hahmo, jonka taidamme nykyään tuntea ainoastaan arkiston asiakirjoista.

Folkloristiikan dosentti Karina Lukin tutkii elävien ja kuolleiden nenetsien arkistoitua perinnettä. 